\title{
Implementation Plan for the Southern Pacific Border and Sierra-Cascade Mountains Provinces
}

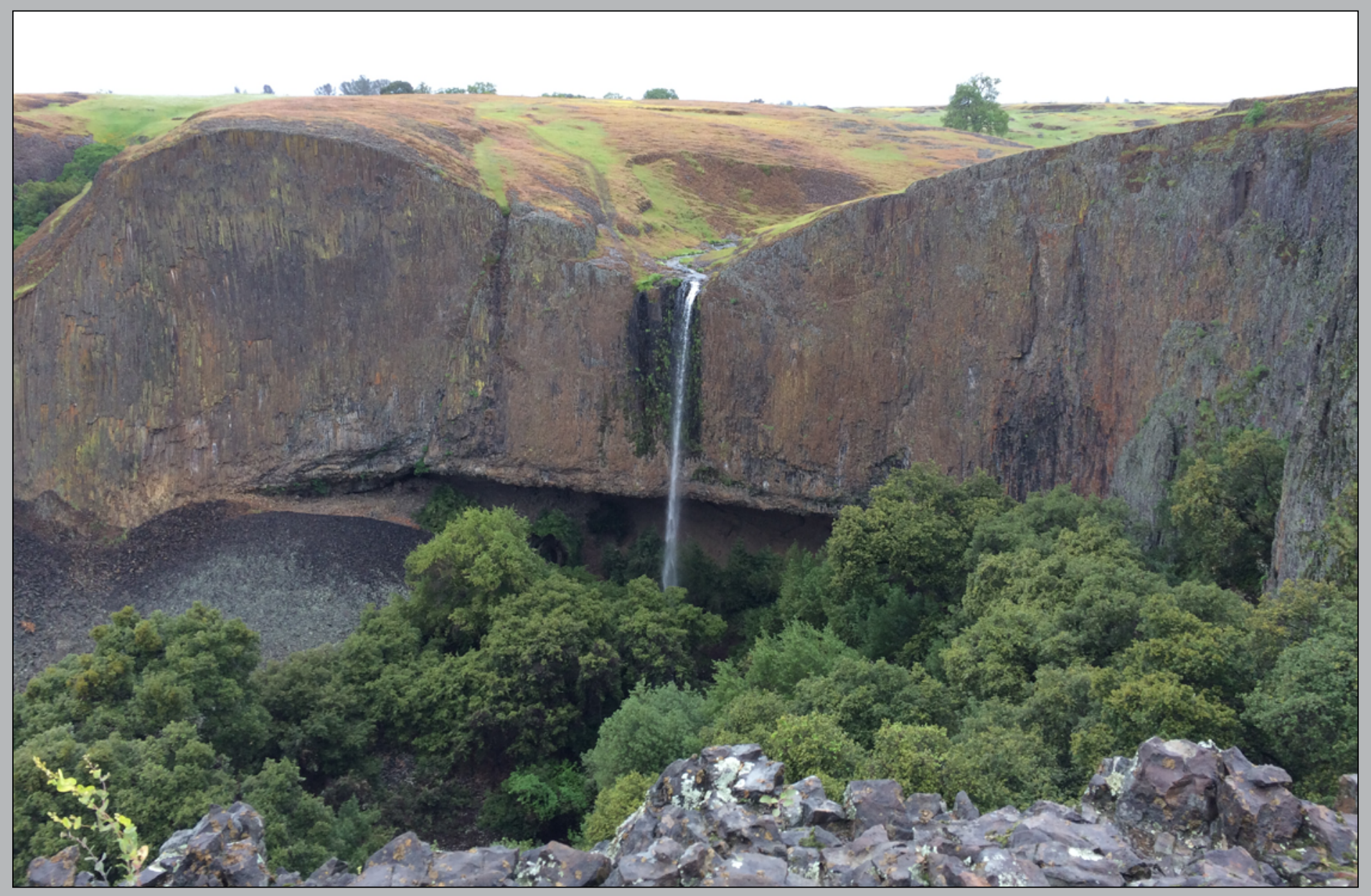

Open-File Report 2021-1012 
Cover. Photograph showing Lovejoy Basalt ( 15-16 million years old) at North Table Mountain near Oroville, California. This flow originated in the northeastern Sierra Nevada and flowed more than 200 kilometers across the Sierra Nevada into the Sacramento Valley, where it is mostly concealed, to as far south as Vacaville (almost to the San Francisco Bay). U.S. Geological Survey photograph taken April 6, 2017, by Victoria Langenheim. 


\section{Implementation Plan for the Southern Pacific Border and Sierra-Cascade Mountains Provinces}

By Victoria E. Langenheim, Russell W. Graymer, Robert E. Powell, Kevin M. Schmidt, and

Donald S. Sweetkind

Open-File Report 2021-1012 


\section{U.S. Geological Survey, Reston, Virginia: 2021}

For more information on the USGS - the Federal source for science about the Earth, its natural and living resources, natural hazards, and the environment—visit https://www.usgs.gov or call 1-888-ASK-USGS (1-888-275-8747).

For an overview of USGS information products, including maps, imagery, and publications, visit https://store.usgs.gov.

Any use of trade, firm, or product names is for descriptive purposes only and does not imply endorsement by the U.S. Government.

Although this information product, for the most part, is in the public domain, it also may contain copyrighted materials as noted in the text. Permission to reproduce copyrighted items must be secured from the copyright owner.

Suggested citation:

Langenheim, V.E., Graymer, R.W., Powell, R.E., Schmidt, K.M., and Sweetkind, D.S., 2021, Implementation plan for the southern Pacific Border and Sierra-Cascade Mountains provinces: U.S. Geological Survey Open-File Report 2021-1012, 11 p., https://doi.org/10.3133/ofr20211012.

ISSN 2331-1258 (online) 


\section{Contents}

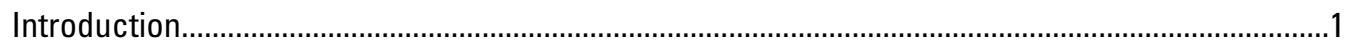

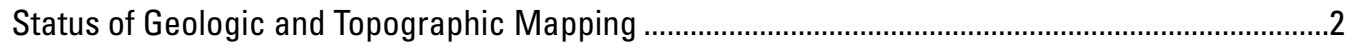

Synopsis of Recent NCGMP-Sponsored Science and Mapping ..............................................

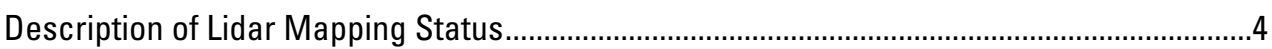

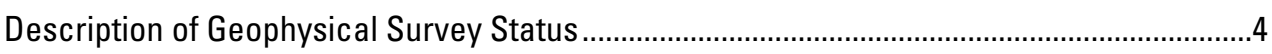

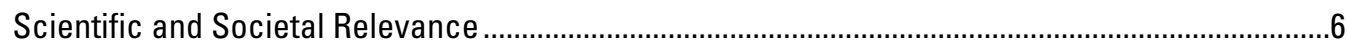

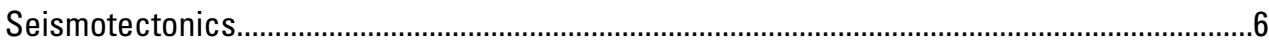

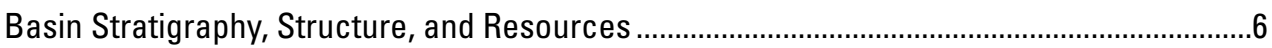

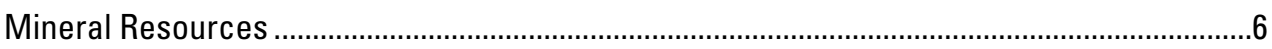

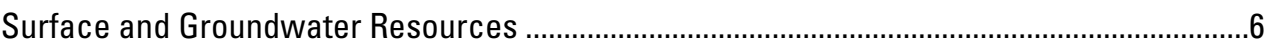

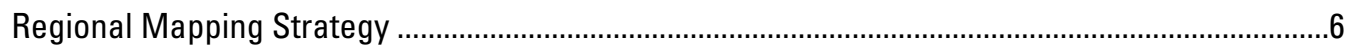

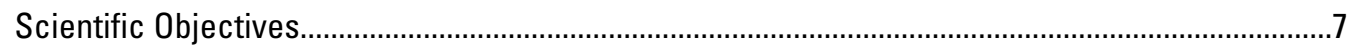

Phase 1 Scientific Objectives ...................................................................................................

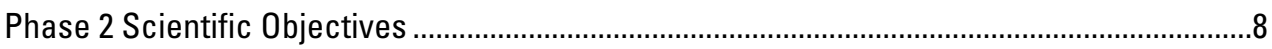

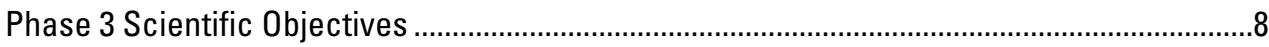

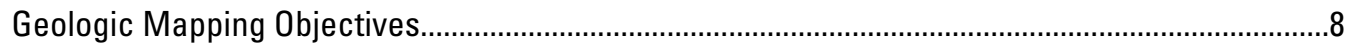

Phase 1 Geologic Mapping Objectives ...................................................................................

Mapping Objective 1. Merge and Update 3D Maps of Different Resolution and Content........ 8

Mapping Objective 2. Geologic and Geophysical Mapping in Areas of Poor Coverage along the Transform Margin ......................................................................................9

Mapping Objective 3. Regional Compilation of a 1:250,000-Scale Seamless Geologic

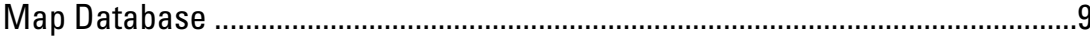

Mapping Objective 4. New Detailed Geologic Mapping in Support of Fellow Department of Interior Agencies ...........................................................................9

Mapping Objective 5. New Mapping in Support of 3D Mapping and (or) Regional Compilations...................................................................................................

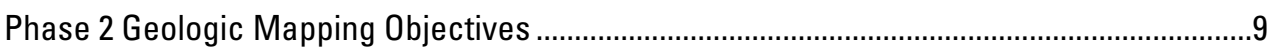

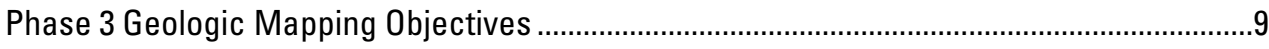

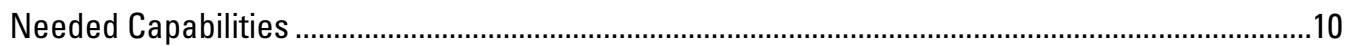

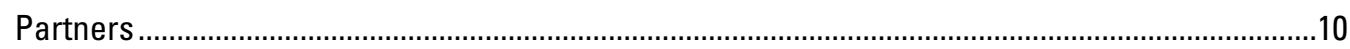

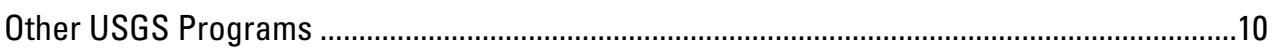

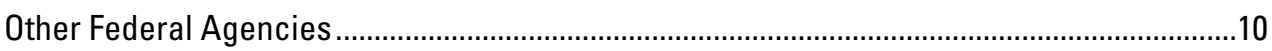

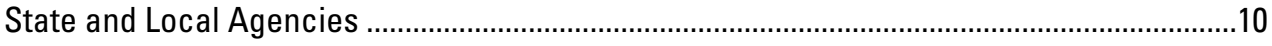

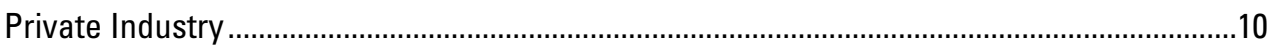

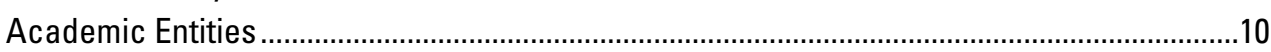

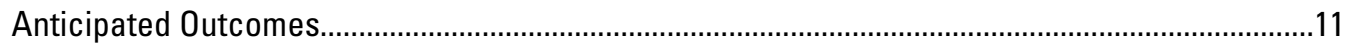

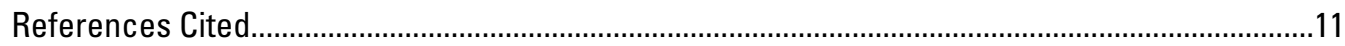




\section{Figures}

1. Map showing the extent of the southern Pacific Border and Sierras-Cascade Mountains provinces in California and Nevada

2. Map of California and Nevada showing 1:24,000- and smaller scale published map coverage in the National Geologic Map Database catalog

3. Map of FEDMAP- and STATEMAP-funded mapping efforts from 2015 to 2020 in the southern Pacific Border and Sierra-Cascade Mountains provinces in California and Nevada

4. Map of California and Nevada showing the footprints of three-dimensional maps for the first and second phase.

5. Map of existing or funded light detection and ranging (lidar) data coverage within the southern Pacific Border and Sierra-Cascade Mountains provinces .

6. Map showing the status of aeromagnetic survey availability and quality in the southern Pacific Border and Sierra-Cascade Mountains provinces.

\section{Abbreviations}

$3 \mathrm{D}$

3DEP

4D

BALANCE

CGS

CRADA

Earth MR

GIS

lidar

MRP

NCGMP

NPS

SAFSOC

USGS three dimensional

3D Elevation Program

four dimensional

Basin and Landscape Co-Evolution

California Geological Survey

Cooperative Research and Development Agreement

Earth Mapping Resources Initiative

Geographic Information Systems

light detection and ranging

Mineral Resources Program

National Cooperative Geologic Mapping Program

National Park Service

San Andreas Fault System in Southern California

U.S. Geological Survey 


\title{
Implementation Plan for the Southern Pacific Border and Sierra-Cascade Mountains Provinces
}

\author{
By Victoria E. Langenheim, Russell W. Graymer, Robert E. Powell, Kevin M. Schmidt, and Donald S. Sweetkind
}

\section{Introduction}

The National Cooperative Geologic Mapping Program (NCGMP) is publishing a strategic plan titled Renewing the National Cooperative Geologic Mapping Program as the Nation's Authoritative Source for Modern Geologic Knowledge (Brock and others, in press). The plan provides a vision, mission, and goals for the program during the years 2020-2030, which are:

- Vision.-Create an integrated, three-dimensional, digital geologic map of the United States.

- Mission.-Characterize, interpret, and disseminate a national geologic framework model of the Earth through geologic mapping.

- Goal.-Focus on geologic mapping as a core function of the U.S. Geological Survey (USGS) within the long-term vision of adequately mapping the Nation's geologic framework in three dimensions.

In order to achieve the goals outlined in the strategic plan, the NCGMP has developed an implementation plan. This plan will guide the annual review of projects carried out by USGS staff (FEDMAP) described in the plan and the development of the annual FEDMAP prospectus that will ensure the effective application of the NCGMP strategy.

This publication describes the implementation plan of the NCGMP strategy for the southern Pacific Border and SierraCascade Mountains provinces, as defined by Fenneman (1917, 1928, and 1946). This implementation plan focuses on the geology of California and a sliver of Nevada surrounding Lake Tahoe (fig. 1). The southern Pacific Border and Sierra-Cascade Mountains provinces encompass the varied landscapes of the high Sierra Nevada, the Central Valley, and Coast Ranges in northern and central California and the Peninsular Ranges, Continental Borderland, Los Angeles Basin-San Gabriel-San Bernardino valleys, western and central Transverse Ranges, and northernmost Salton Trough in southern California. Societal demands create a need for earth-science data in each of these landscapes. The broader San Francisco Bay area, Central Valley, Los Angeles-San Gabriel-San Bernardino lowlands, and the coastal lowlands that border the Peninsular Ranges are densely populated (about 30 million people) areas at high risk of natural hazards. The mountains of the Sierra Nevada, Peninsular Ranges, and Transverse Ranges, and the coast all provide numerous recreational opportunities that attract visitors from around the world, whereas previously these ranges attracted people to mine their resources. The agricultural capacity of the Central Valley is a critical resource for the Nation that is increasingly water limited.

The southern Pacific Border and Sierra-Cascade Mountains provinces, at the edge of the North American continent, were profoundly influenced by subduction zone tectonics during the Mesozoic and early Cenozoic (ongoing in northernmost California) and subsequently by the inception, development, and present activity of the San Andreas transform margin system. Although the geology of this region is the poster child of fundamental conceptual models of subduction zone complexes, forearc basins, ophiolite obductions, magmatic arcs, and suspect terranes, as well as hosting one of Earth's most notorious continental transform faults - the San Andreas Fault - important questions that have important societal consequences remain to be answered. Most of California's population reside in these provinces and live within 30 miles of an active fault (according to www.earthquakeauthority.com) yet new faults continue to be discovered, highlighting the importance of deformation off the main San Andreas Fault. Bedrock, surficial, and three-dimensional (3D) geologic maps depicting stratigraphic structure and depth to crystalline basement rocks provide critical context and information for understanding fault rupture, distributed deformation, fault connectivity, and history in addition to providing crucial data that enable forecasting of shaking amplitude and length from hypothetical earthquake scenarios.

The tectonic evolution of California produced not only stunning mountains, with associated hazards from landslides and active volcanoes, but also fertile valleys that make California the top agricultural producer in the country in terms of cash receipts (according to www.ers.usda.gov/faqs). These valleys lie atop large basins that not only store groundwater but, in many cases, host oil and gas fields, contributing to the fourth highest hydrocarbon production by State in the country in 2016 (according to https:// www.aei.org/carpe-diem/animated-chart-of-us-oil-production-bystate-1981-2017). Water is a key resource increasingly stressed by growing agricultural, industrial, and residential needs. Warmer and drier conditions have led to an increased reliance on extracting groundwater resources, whose availability and quality are dictated at the first order by the 3D spatial distribution of bedrock and Quaternary surficial deposits. Thus, assessment of this critical resource is inextricably tied to knowledge of the surficial and subsurface geologic structure and material types. 


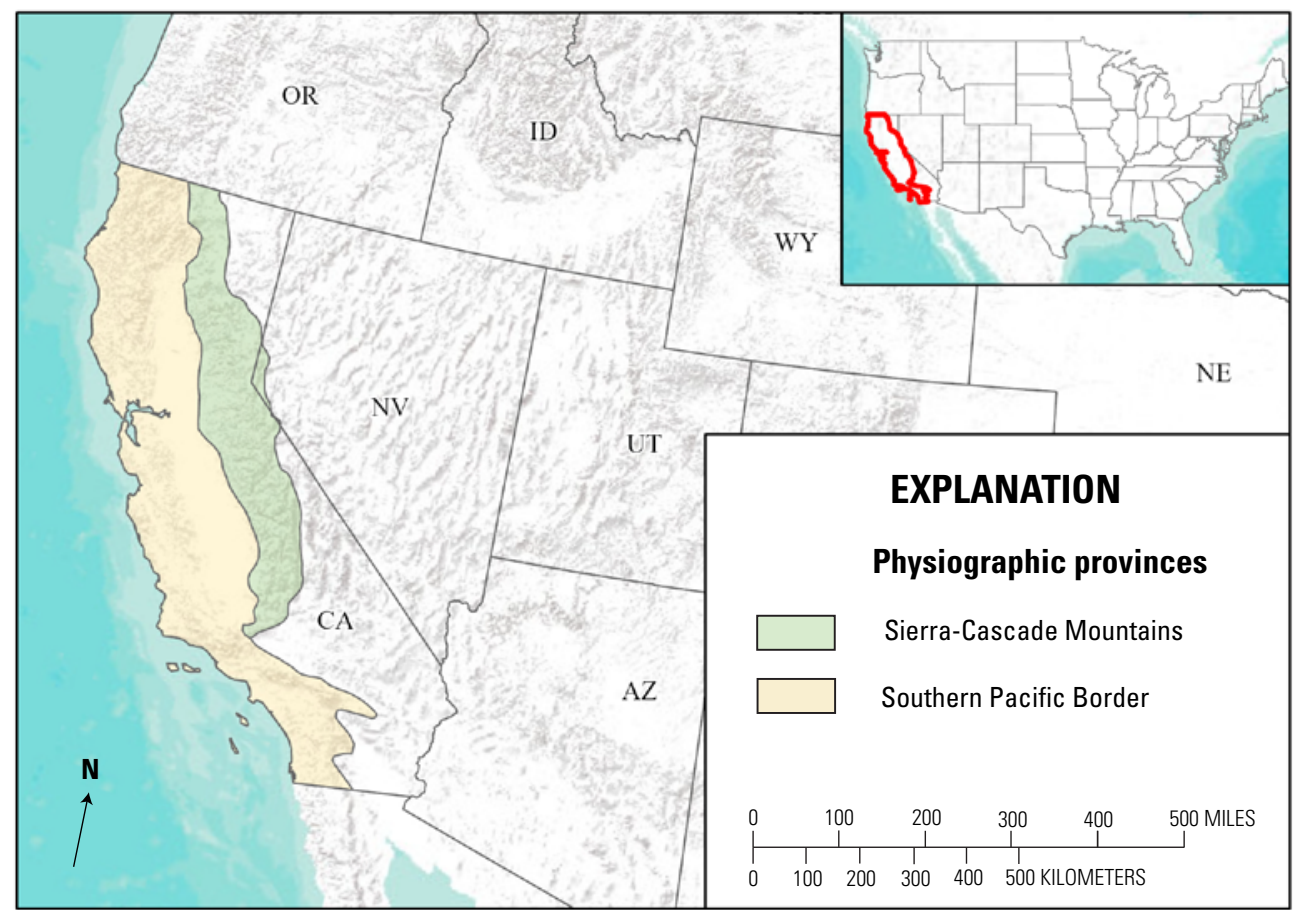

Figure 1. Map showing the extent of the southern Pacific Border and Sierra-Cascade Mountains provinces in California and Nevada. AZ, Arizona; CA, California; ID, Idaho; NE, Nebraska; NV, Nevada; OR, Oregon; UT, Utah.

\section{Status of Geologic and Topographic Mapping}

Previous mapping efforts in the provinces span multiple scales from 1:24,000 to 1:250,000 and multiple decades (fig. 2). Many of the previous 1:24,000-scale maps, for example, in the California Coast Ranges, are from Thomas Dibblee, based on his mapping efforts in the 1950s and 1960s. Since then, mapping and dating methods have substantially changed and improved. Although substantial progress has been made by State and Federal surveys, notable gaps exist, especially at scales of 1:24,000 away from densely populated areas. Although the entire State is covered at a mapped scale of 1:250,000, most of these maps predate the 1980s, are not seamless, and in some cases, such as the Alturas and Ukiah quadrangles, have blank areas.

\section{Synopsis of Recent NCGMP-Sponsored Science and Mapping}

Because of the provinces' geologic complexity and the high degree of societal relevance, the NCGMP has a longstanding footprint in the provinces, including the projects listed below carried out by USGS staff (FEDMAP). Maps and data developed during these projects and by State geological surveys (STATEMAP) (figs. 3 and 4) provide an important springboard for future work in the provinces.

- 2003-2008, Understanding Geohydrologic Systems from Geologic Framework and History, project chief: V.E. Langenheim

- 2008-2013, Geohydrology of Coast Ranges Basins, project chief: V.E. Langenheim

- 2013-2018, Geologic Controls on Hydrology in Sacramento Valley and Other Basins, California, project chief: V.E. Langenheim

- 2007-2011, 3D/4D Mapping of the San Andreas Fault Zone, project chief: R.W. Graymer

- 2010-2018, Seismic Hazards in the Sacramento Delta, project chief: R.W. Graymer

- 2004-2011, Basin and Landscape Co-Evolution (BALANCE), project chief: J.C. Matti

- 2011-2016, San Andreas Fault System in Southern California (SAFSOC), project chief: R.E. Powell

- 2016-2021, San Andreas Fault System in Southern California 2 (SAFSOC 2), project chief: R.E. Powell 


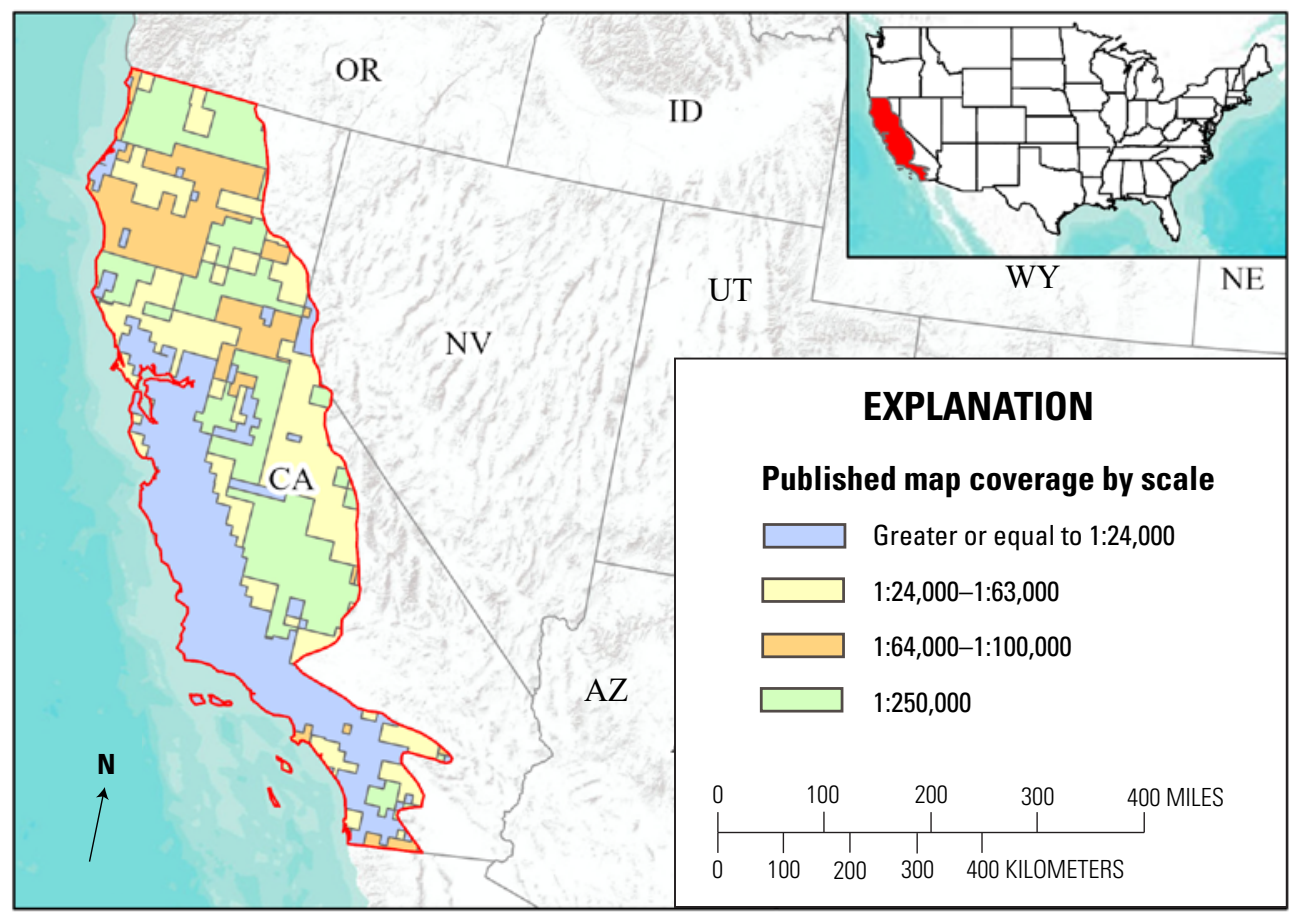

Figure 2. Map showing the scale of existing published map coverage in the National Geologic Map Database catalog. Not depicted are three-dimensional geologic maps. The red outline shows the southern Pacific Border and Sierra-Cascade Mountains provinces in California and Nevada. AZ, Arizona; CA, California; ID, Idaho; NE, Nebraska; NV, Nevada; OR, Oregon; UT, Utah; WY, Wyoming.

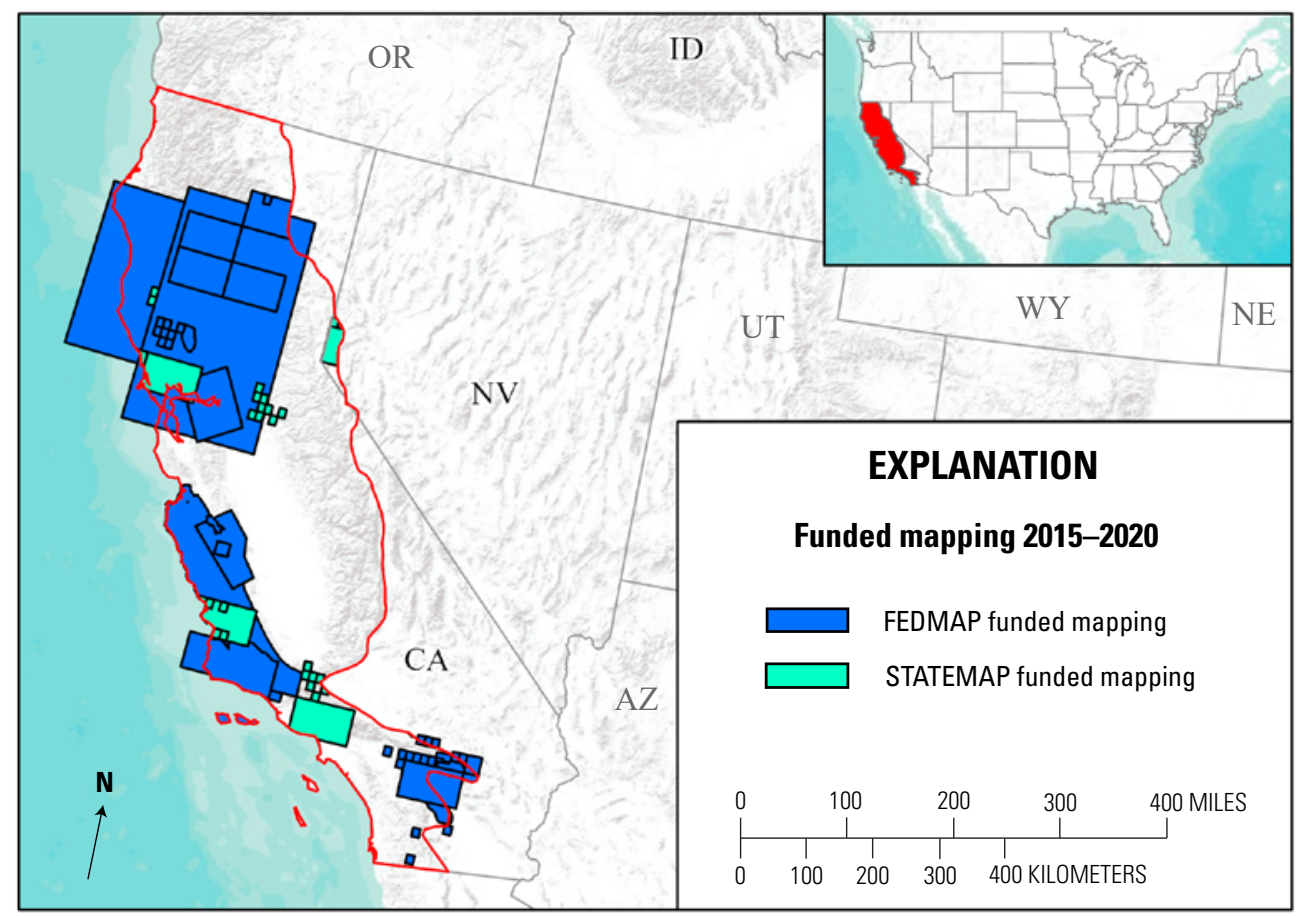

Figure 3. Map of FEDMAP- and STATEMAP-funded mapping efforts from 2015 to 2020 in the southern Pacific Border and Sierra-Cascade Mountains provinces in California and Nevada (red outline). AZ, Arizona; CA, California; ID, Idaho; NE, Nebraska; NV, Nevada; OR, Oregon; UT, Utah; WY, Wyoming. 


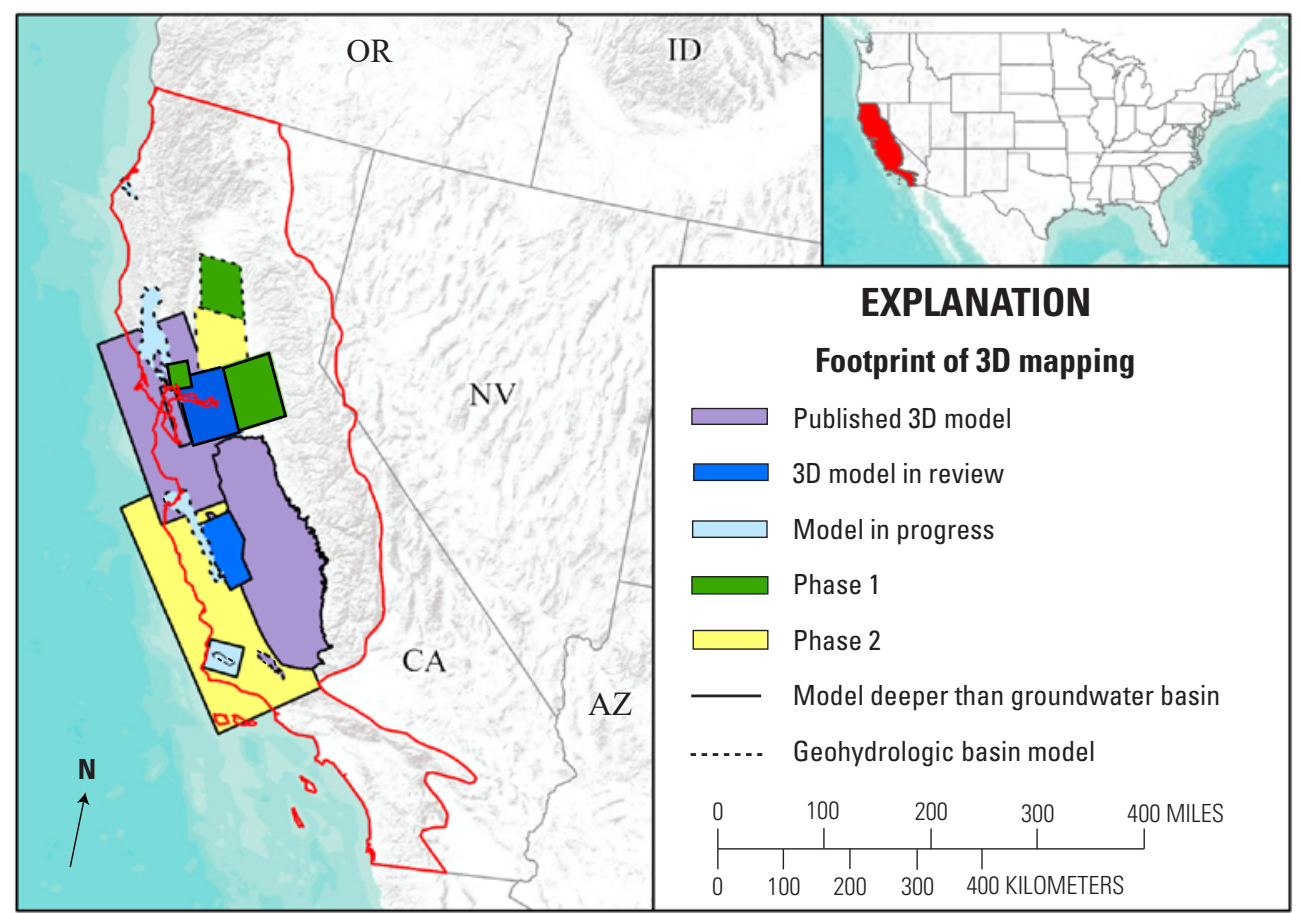

Figure 4. Map of footprints of three-dimensional (3D) maps for the first and second phase proposed in this plan in addition to maps in various stages of publication from previous, related projects. Solid outlines denote models that extend deeper than the groundwater basin; dashed lines indicate geohydrologic basin models. Red outline shows the southern Pacific Border and Sierra-Cascade Mountains provinces in California and Nevada. AZ, Arizona; CA, California; ID, Idaho; NV, Nevada; OR, Oregon.

\section{Description of Lidar Mapping Status}

Although not critical for small-scale geologic mapping, high-resolution topographic data are critical for mapping at scales of 1:100,000 or finer, especially for mapping of surficial deposits and their attendant hazard susceptibility, and for identification of young fault traces.

Light detection and ranging (lidar) data provide highresolution topographic data that aids fine-scale geologic mapping. In the southern Pacific and Sierra-Cascade Mountains provinces, these data exist for much of the San Francisco Bay area, Sacramento River delta region, and in parts of the Sierra Nevada and Transverse Ranges (fig. 5). Lidar data are absent in several key areas, including (1) the north ends of the San Andreas and Bartlett Springs Faults and the Mendocino triple junction region, (2) the Transverse Ranges, (3) much of the Sacramento and San Joaquin Valleys, and (4) much of the Klamath Mountains, Cascade Range, and Modoc Plateau in northernmost California. Much of the areas listed in areas 1 and 4 have been identified as areas of 3D
Elevation Program (3DEP) interest but are currently without funding (fig. 5).

\section{Description of Geophysical Survey Status}

Aeromagnetic and gravity data can be used to map physical properties related to geologic structure and stratigraphy, allowing mapping of geologic relations across areas covered by young surficial deposits or into the subsurface. Airborne magnetic surveys can be an efficient and effective way to map magnetic properties of crustal rocks over large areas. A recent compilation of airborne magnetic surveys (Drenth and Grauch, 2019; Johnson and others, 2019; fig. 6) indicates that much of coastal California north of the Transverse Ranges has suitable resolution to contribute to 1:100,000-scale (or finer) studies. Substantial gaps (blue and gray in fig. 6) exist in northwestern California, San Joaquin Valley, and parts of the Sierra Nevada. Likewise, gravity data are non-uniformly distributed throughout the province. 
Figure 5. Map of existing or funded light detection and ranging (lidar) data coverage within the southern Pacific Border and SierraCascade Mountains provinces. Although not critical for small-scale geologic mapping, high-resolution topographic data are critical for mapping at scales of 1:100,000 or finer, especially for mapping of surficial deposits, their attendant hazard susceptibility, and for identification of young fault traces. Red outline shows the southern Pacific Border and Sierra-Cascade Mountains provinces in California and Nevada. 3DEP, 3D Elevation Program; Earth MRI, Earth Mapping Resources Initiative; $A Z$, Arizona; CA, California; ID, Idaho; NE, Nebraska; NV, Nevada; OR, Oregon; UT, Utah; WY, Wyoming.

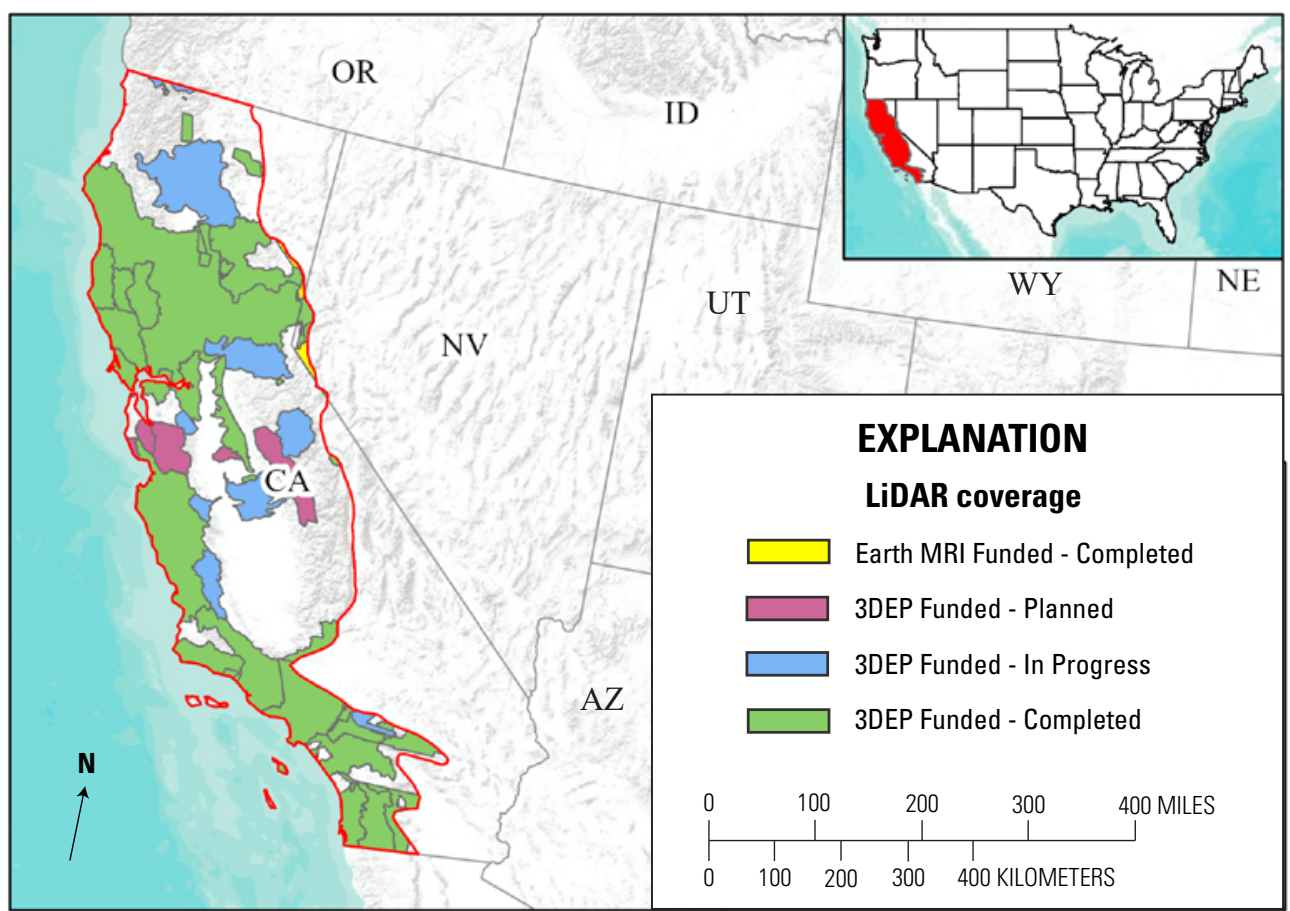

Figure 6. Map showing the status of aeromagnetic survey availability and quality in the southern Pacific Border and Sierra-Cascade Mountains provinces. Areas shown in orange and light green (rank 1 and 2) are of sufficient resolution for mapping at detailed scales, whereas areas in blue and gray (rank 4 and 5) have poor or low resolution and would be considered high priority under the Earth Mapping Resources Initiative. Areas shown in green (rank 3 ) are of suitable resolution for mapping at regional scales. Not shown are very detailed, ground-based gravity and magnetic measurements. Modified from Drenth and Grauch (2019). Red outline shows the southern Pacific Border and Sierra-Cascade Mountains provinces in California and Nevada. $A Z$, Arizona; CA, California; ID, Idaho; NV,

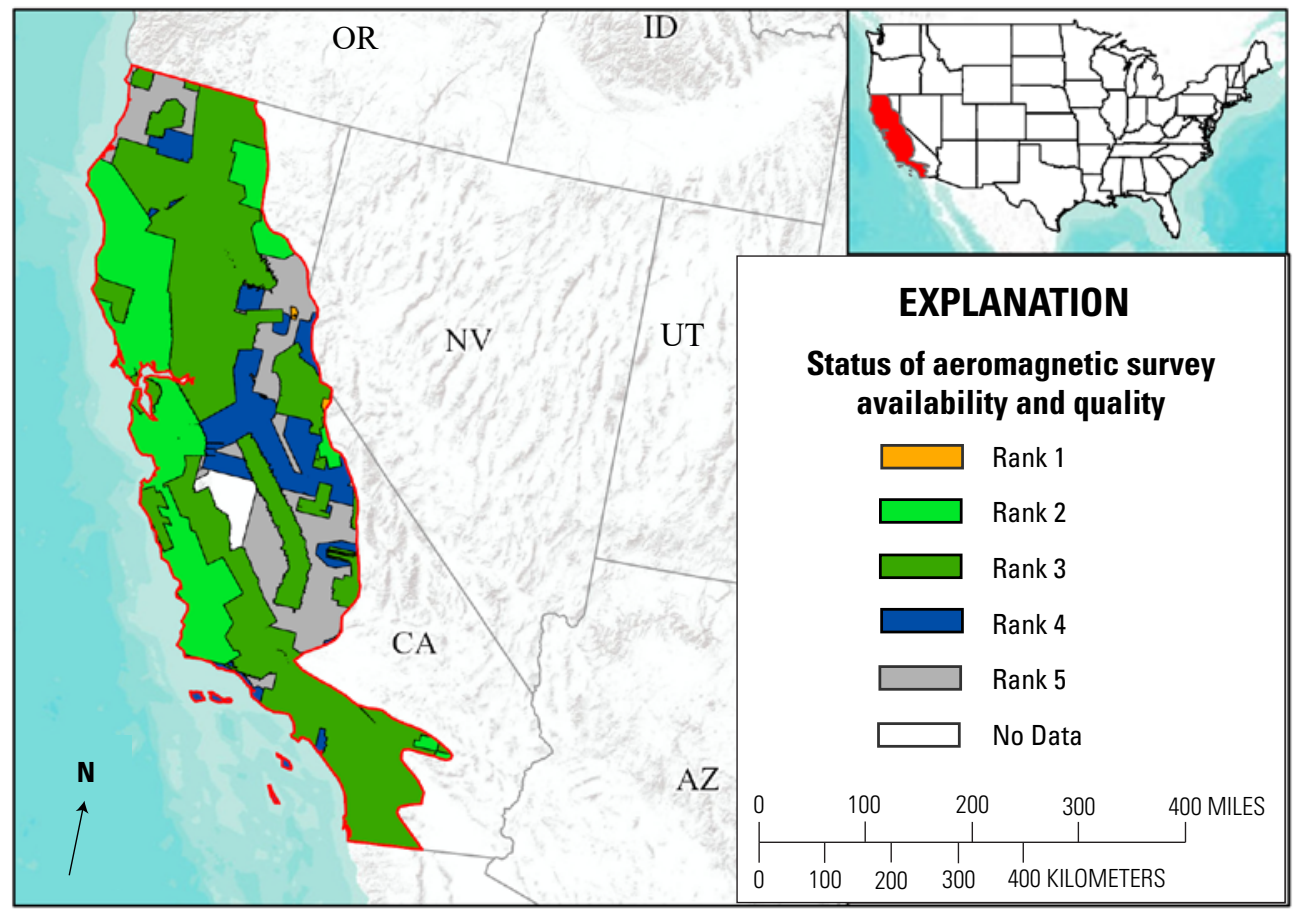
Nevada; UT, Utah. 


\section{Scientific and Societal Relevance}

Scientific and societal relevance in the southern Pacific Border and Sierra-Cascade Mountains provinces are inextricably intertwined. For example, the large region that includes the urban San Francisco Bay and Los Angeles areas lies along the transform plate boundary where societal impacts of geologic processes are extremely high; however, the 3D and four-dimensional (4D) geology, which is the geology as it changed over time, underlying this region remains poorly known. Fundamental questions about the tectonic framework and geologic development of this area remain unanswered, such as the relation between thrust and strikeslip faults, the relative age of numerous faults, and the partitioning of slip amongst them.

The West Coast of the United States contains valleys that are the focus for human effects, such as urbanization and agriculture. The basins that underlie these valleys are increasingly affected by the availability and sustainability of water resources owing to ongoing urbanization outside the main coastal metropolitan areas. Many of the valley areas contain substantial aquifers that are important sources of local groundwater for domestic, agricultural, and municipal use. These aquifers are increasingly stressed, resulting in falling groundwater levels, water-quality issues, such as salt-water intrusion where some of these valleys are in close proximity to the ocean, and subsidence. The subsurface geology in these basins results from the interplay of the depositional and deformational processes through time, yet the geologic history and basin evolution remain poorly understood and a priority for scientific study.

Specific topics that have combined scientific and societal relevance are discussed below.

\section{Seismotectonics}

Important questions of how fast faults slip through time, how they are connected at depth and at the surface, how to interpret geodetic data relating to the style of deformation, and how rocks of different density and seismic velocity are distributed pertain directly to societally relevant questions of how to forecast shaking damage, the size of potential earthquakes, and where faults may rupture.

\section{Basin Stratigraphy, Structure, and Resources}

Basins preserve the record of the tectonic evolution, unroofing (exhumation), and sedimentation of California. Their structural and stratigraphic underpinnings are essential components for understanding availability and quality of natural resources, particularly water, oil, and gas, as well as understanding seismic path and basin effects that concentrate shaking in certain areas.

\section{Mineral Resources}

Basic geologic, geophysical, and geochemical map information is critical to understanding where mineral resources may be present, not only at the surface, but in the subsurface. The discovery of gold in the foothills of the Sierra Nevada led, in large part, to California becoming the 31 st State of the Union. Although gold mining is now largely absent from the southern Pacific Border and Sierra-Cascade Mountains provinces, the arc setting and accompanying rocks affected by hydrothermal and epithermal processes may host critical minerals, such as tungsten, chromium, and rare earth elements.

\section{Surface and Groundwater Resources}

Within the province, surface water and groundwater serve as water supplies for urban populations, agriculture, and native habitats. The combination of rapid population growth, high water use, and an increasingly arid climate has led to an increased dependence on groundwater resources, resulting in locally severe groundwater depletion, declining groundwater levels, and local subsidence of the land surface. Management of surface-water and groundwater resources in the provinces requires knowledge of the groundwater system, which requires an understanding of the configuration and properties of aquifers. Such understanding includes the delineation of water-bearing units based on lithology and hydraulic properties, and the construction of two-dimensional (2D) and 3D hydrogeologic frameworks.

\section{Regional Mapping Strategy}

In order to understand the temporal and spatial evolution of California landscapes, three coevolving groups of landform features must be integrated: (1) mountain ranges, carved principally from uplifted crustal blocks of igneous and metamorphic crystalline basement rocks and (or) unmetamorphosed Mesozoic and early Cenozoic strata; (2) lowland valleys, filled with late Cenozoic sedimentary materials; and (3) mountain fronts that form dynamic interfaces between the highland blocks and lowland basins. These three physiographic elements record distinct but complementary records of landscape evolution. The geologic story of most of California over the last 30 million years or so has been driven by evolving plate-margin interactions between the Pacific and North America Plates; understanding that story depends on documenting the origin and interactive evolution of fault-bounded crustal blocks at various scales.

This implementation plan outlines a multi-pronged approach that builds on, updates, and merges recent 2D and 3D mapping funded by FEDMAP (figs. 3 and 4) while filling in gaps of knowledge in key areas with new detailed mapping supplemented by a compilation of mapping from other sources. These efforts will set the stage for a unified geologic map that will contribute to hazard and resource studies within this geologically complex and active province.

The regional mapping strategy will use surface and subsurface geologic mapping and potential field geophysical studies - accompanied by stratigraphic, paleontological, geochronological, and geochemical studies - both (1) to 
construct a 4D crustal framework for understanding the occurrence and risk of hazards (earthquake, volcanic, landslide, flood, and fire) in space and time and (2) to evaluate the distribution of and temporal changes in resources (water, soil, mineral, oil and gas, geothermal, aggregate, and biota and habitat). We will also use these mapping studies to document evidence for the earth processes involved in generating hazards and affecting the availability of resources.

Regional mapping of the southern Pacific Border and Sierra-Cascade Mountains provinces will proceed on several fronts: (1) 1:24,000- to 1:100,000-scale mapping activities conducted by FEDMAP and STATEMAP projects where geologic detail is required for scientific understanding or hazard or resource purposes; (2) regional geologic map compilation at 1:250,000 scale supporting the development of a nationwide seamless geologic map database; (3) basin-scale $3 \mathrm{D}$ geologic maps that are primarily focused on water-bearing strata in the upper 1-2 kilometers of the crust; and (4) crustalscale 3D geologic maps primarily focused on faults at depths that can produce earthquakes and $3 \mathrm{D}$ crustal properties.

\section{Scientific Objectives}

Objectives are broken up into three 4-year phases, yet the complexity of the geology and prior experience dictate that there will be geographic overlap between these phases. For example, the passage of the Sustainable Groundwater Management Act (for more information, visit https://www.water.ca.gov/Programs/ Groundwater-Management/SGMA-Groundwater-Management) has elevated the demand for geologic framework models of groundwater basins and the ability to update pertinent geologic maps with higher resolution surface and subsurface data for specific basins. The high probability of a major earthquake in the next 12 years may also modify mapping priorities. There are overarching scientific questions and themes that span all the phases.

1. What are the geometry, slip rate, and connectivity of faults throughout the transform margin? How do these faults affect resource location, distribution, quantity, and quality? How do these factors contribute to the behavior of faults as earthquake sources?

2. How have basins and landscapes evolved through time? How has this evolution affected resource quantity and quality? Can we use this knowledge to better understand processes related to hazards and resources?

3. How are rocks and sediments of different properties distributed at the Earth's surface and in the upper crust? How does this distribution affect resource quantity and quality? How does this distribution affect propagation of seismic energy and ground shaking? How does this distribution affect landslide hazard and post-fire erosion? How do we best assign physical and hydrological properties to rock and sediment volumes?
What follows are descriptions of the scientific objectives for each of the three 4-year phases. The objectives are tied to the themes listed above and directly to activities in each phase.

\section{Phase 1 Scientific Objectives}

1. Where and how does slip that is not on the mapped San Andreas Fault occur? How does deformation in the Walker Lane connect with the propagation of the Mendocino triple junction? Where and how does strain transfer off of the southern San Andreas Fault into the Eastern California Shear Zone?-A substantial amount of slip transfers off the southern San Andreas Fault southward onto the San Jacinto Fault and northward into the Eastern California Shear ZoneWalker Lane of the Mojave Desert and along the eastern margin of the Sierra Nevada. Continued assessment of the geometry, recency, and amount of slip on various faults in the broad transform margin remains a high societal and scientific priority.

2. Improving assignment of seismic velocity to subsurface volumes to enable more accurate estimation of ground shaking from hypothetical earthquake scenarios.-As part of our ongoing development of 3D geologic maps of the region, new 3D geologic mapping of the eastern Sacramento Valley and Sierra Nevada foothills, which will extend from the completed but not yet published Delta 3D map, will encompass a volume with an upper basement surface that is well defined by basement penetrating wells. A closely defined basement surface, combined with the somewhat unreliable identification of basement rocks in wells, will eliminate uncertainties involved in using gravity and aeromagnetic data to assign density and seismic velocity to basement volumes. Having a geology-based 3D model with well-defined basement properties will enable direct comparison to tomographic models of the same volume, an important step toward developing techniques to produce superior 3D seismic velocity models that take advantage of both geologic and tomographic data.

3. What are the geologic controls on large-volume springs and groundwater flow within the volcanic section, which is the recharge area and headwaters of the Sacramento River? What is the $3 D$ subsurface configuration of aquifers and confining units in major groundwater basins, such as the Sacramento and Salinas valleys? - The northward propagation of the zone of right-lateral shear in eastern California extends into the southernmost Cascade Arc in northeastern California. This region hosts large-discharge springs that feed the most important tributary that provides the largest discharge to the Sacramento River headwaters. Given evidence of young faulting that displaces Quaternary volcanic rocks, this region, where the Walker Lane, Cascade Arc, and Basin and Range province intersect, has a surprisingly substantial gap of geologic mapping, even at a scale of 1:250,000. Although geologists in the Volcano 
Hazards Program (of the California Volcano Observatory) are mapping the region between Lassen Peak and Mount Shasta, their efforts are not focused on the geohydrologic framework of the area and could be augmented by geophysical constraints.

\section{Phase 2 Scientific Objectives}

As mentioned above, there are overarching scientific objectives for the region that will continue throughout the phases of study planned here. Experience has shown that prioritizing specific scientific questions within those overarching objectives is a fluid exercise. New scientific questions are developed during the answering of existing questions or are generated by events like large earthquakes. Specific scientific questions may also be prioritized based on needs of partners and collaborators, as well as changing societal drivers, such as drought, land development, or resource requirements. Therefore, prioritizing scientific questions beyond phase 1 should be interpreted as our current view, and not a definitive statement of what priorities will be 4 or 8 years from now.

Scientific questions that would logically follow those listed for phase 1 include:

1. How is slip accommodated as a result of the Transverse Ranges rotation?

2. When and how did the big bend in the San Andreas Fault form?

3. How do faults east of the San Andreas Fault interact with the subduction zone north of Cape Mendocino?

Rotation of the Transverse Ranges and development of the "big bend" in the San Andreas Fault have a profound influence on the geology of southern California. However, slip evolution through time north of the Transverse Ranges in the central California Coast Ranges is only known in a few places and is a subject of debate. Several models propose when the "big bend" in the San Andreas Fault formed, but data to test these models are inadequate. New constraints from targeted mapping and development of 3D models through time can provide a different approach to addressing these questions.

The San Andreas Fault ends at the Mendocino triple junction, yet strike-slip faults to the east appear to continue north. How much slip is carried north of the triple junction, how these faults interact with the subduction zone, or how deformation is associated with the clockwise rotation of the Oregon block are not well known. Research based on these questions will address aspects of the subduction zone that could leverage efforts of the North Pacific province projects and the Earthquake and Coastal and Marine programs, especially if the subduction zone initiative expands.

\section{Phase 3 Scientific Objectives}

Develop province-wide 2D and 3D subsurface maps of structural features (faults and folds), stratigraphic unit extent, elevation, and thickness that will lead to province-wide scientific understanding of the geologic, stratigraphic, structural, and tectonic evolution of the region.

\section{Geologic Mapping Objectives}

The following sections describe the geologic mapping objectives for each of the three phases. Objectives are tied to themes and scientific objectives described above and directly to activities in each phase.

\section{Phase 1 Geologic Mapping Objectives}

The first phase will consist of several main mapping objectives.

\section{Mapping Objective 1. Merge and Update 3D Maps of Different Resolution and Content}

A major effort is to create a new 3D geologic map of eastern Sacramento Valley and the Sierra Nevada foothills. This effort extends the existing Delta 3D and San Francisco Bay 3D maps and supports the scientific objective listed above. It will also help improve the 3D seismic velocity model and associated earthquake hazard studies in this region.

As part of our ongoing effort to update and combine 3D geologic maps, in collaboration with USGS Earthquake Science Center, we will develop strategies to integrate revised 3D map volumes and seismic velocity models into existing maps and models devoid of map boundary discontinuities that will impair their use for modeling seismic wave propagation and earthquake shaking. We intend to use the volume around the recent magnitude 6.0 Napa earthquake as a test case, developing a more detailed model of the 3D geology in a way that can be smoothly integrated into the existing model. This work will also benefit from ongoing efforts to develop new techniques to analyze potential-field data.

As part of our effort to extend and improve 3D geologic maps, we will compare a new, relatively detailed, geology-based 3D seismic velocity model with a detailed seismic refraction experiment completed as part of the central Coast Ranges Pacific Gas and Electric (PG\&E) Cooperative Research and Development Agreement (CRADA) work over the last decade. Like the work described above for the eastern Sacramento Valley and Sierra Nevada foothills, this comparison would contribute to development of techniques to combine geology-based 3D seismic velocity models with models derived from other datasets.

Abundant geophysical and subsurface geologic data will be used to construct a digital basin-scale 3D geologic framework in the structurally complex central California Coast Ranges. With CRADA funding, the 3D mapping could be expanded to crustal scale and include deep structure and crustal block boundaries. This effort ties together existing San Francisco Bay, San Andreas Fault, and Santa Maria 3D maps and supports the scientific objective listed above. It also leverages external funding and supports cooperative research goals. 
Mapping Objective 2. Geologic and Geophysical Mapping in Areas of Poor Coverage along the Transform Margin

This effort will consist of two areas of mapping. The first, building on NCGMP efforts currently underway as we move into phase 1, consists of detailed mapping in southern California to determine how slip transfers off of the mapped San Andreas Fault north into the Eastern California Shear Zone and south onto the San Jacinto Fault. The second area, in northeastern California, will augment mapping efforts by geologists (mostly emeriti) in the Volcano Hazards Science Center to provide a geohydrologic context. In northeastern California, regional geologic mapping will occur in exposed volcanic rocks that are perhaps California's most amenable place to use combined geologic and geophysical mapping techniques owing to the strong magnetic properties of extensive areas of young volcanic rocks.

\section{Mapping Objective 3. Regional Compilation of a 1:250,000-Scale Seamless Geologic Map Database}

A broad goal of this program is to create a seamless 1:250,000-scale regional geologic map compilation of the Sierra Nevada. This effort will produce a multilayer, multipurpose geologic map compiling the best available geologic and geophysical data for the region. This task will also include an outreach component, providing a nontechnical geologic guide of the region. This task will leverage the knowledge and enthusiasm of emeriti to augment project work by active personnel.

\section{Mapping Objective 4. New Detailed Geologic Mapping in Support of Fellow Department of Interior Agencies}

One part of this objective is to create a 1:24,000-scale map of Pinnacles National Park and vicinity. We will complete mostly finished geologic mapping from previous projects and provide more detailed and updated depiction and interpretation of geologic resources for the eastern half of the national park. This effort also supports the central Coast Ranges 3D geologic map effort listed above and provides constraints on timing and amount of Neogene slip on the San Andreas Fault.

A second part of this objective is to create a 1:24,000scale map of Berryessa Snow Mountain National Monument and its vicinity. This effort involves detailed geologic mapping in a poorly mapped and understood region. We will complete mapping that started with the Delta 3D project to study the uplift rate along the Coast Ranges-Central Valley boundary, which has been modeled as resulting from slip on active blind reverse faults that pose a poorly understood hazard to valley communities and infrastructure. This work will also provide constraints on the geometry of the Berryessa-Bartlett Springs fault connection, which accommodates as much as 9 millimeters per year of right-lateral slip as the easternmost major fault of the San Andreas Fault System. Mapping in this region will provide the basis for future 3D geologic mapping (see mapping objective 5 below).

A third part of this objective is to create 1:12,000-scale Quaternary surficial geologic maps of Channel Islands National Park, which will be generated in collaboration with National Park Service (NPS) research and resource interests. These detailed process- and age-based maps rely heavily on lidar-derived topography and derivative metrics associated with above-ground vegetation characteristics. Map information will be used to evaluate recency of faulting, landslide density and type, activity of eolian processes, and constraints on surface water availability in this water-limited landscape.

\section{Mapping Objective 5. New Mapping in Support of 3D Mapping and (or) Regional Compilations}

Another effort is to create a new geologic map of the Sierra Nevada foothills in the Auburn-Placerville region. This effort builds on unpublished mapping (R.W. Graymer's regional geologic mapping project of the San Francisco Bay region [Ph.D. dissertation]) in a rapidly developing and geologically complex area. This mapping is collaborative with and complementary to current California Geological Survey (CGS) mapping projects and partly lies within an area identified by CGS as high priority but not on their list of planned mapping. This effort will also support both the Sierra Nevada compilation map and eastern Sacramento Valley and Sierra Nevada foothills 3D map (see mapping objectives 1 and 2 above).

\section{Phase 2 Geologic Mapping Objectives}

Phase 2 objectives would expand existing 3D geologic maps outward by incorporating and updating 3D geologic information in the San Joaquin Valley, expanding the central Sacramento Valley model northward, and fully developing a 3D geologic map of the central California Coast Ranges. In the Central California Coast Ranges, 3D geologic mapping techniques would be used to (1) understand the nature of groundwater aquifers (in the Salinas valley and Paso Robles) and hydrocarbon reservoirs (in San Ardo, Santa Maria, and Cuyama districts) in this region, focusing on fault architecture, folding, uplift, and basin stratigraphy, and (2) use the 3D geometry to further understand the evolution of the plate boundary and the partitioning of slip within the San Andreas Fault System. Compilation of the Sierra Nevada geologic map will set the stage for projecting this information into the subsurface.

Mapping will continue at appropriate scales for determining slip history in the area of the "big bend" in the San Andreas Fault and western Transverse Ranges and how it pertains to basin and landscape development.

\section{Phase 3 Geologic Mapping Objectives}

Mapping objectives at phase 3 have not yet been determined to allow flexibility in the project. 


\section{Needed Capabilities}

NCGMP and science center workforce planning efforts will specify long-term staffing needs by addressing critical geologic specialty skill sets required for integrated geologic mapping and research tied to the described societal and scientific priorities. For developing 3D maps, bedrock and surficial geologists with mapping expertise, potential-field geophysicists, and support staff who can work with 3D datasets, software, and enterprise geographic information systems (GIS) are necessary, but opportunities exist for coordinating efforts with USGS Core Science Systems, Natural Hazards, Water Resources, Energy and Minerals, and Ecosystems Mission Areas.

\section{Partners}

One rationale for having NCGMP in the Core Science Systems Mission Area is that geologic and geophysical mapping and related studies result in knowledge that may contribute to efforts underway in several other mission areas. Therefore, NCGMP projects that focus on the southern Pacific Border and Sierra-Cascade Mountains provinces currently - and will continue to - work cooperatively and collaboratively with other programs in the USGS, with other Federal, State, and local agencies, and with academic partners. Most of these collaborative and supportive efforts are especially relevant societally. It is important that NCGMP receive acknowledgment from stakeholders regarding the value and significance of input received from our geologic, geophysical, and stratigraphic studies in facilitating and accomplishing their missions. Ongoing collaborations and societal relevance are listed below.

\section{Other USGS Programs}

- California Water Science Center--NCGMP field investigations serve as the foundation for hydrogeologic modeling by the Water Resources Mission Area.

- Earthquake, landslide, and volcano hazards.-In support of work conducted in the Natural Hazards Mission Area, NCGMP field investigations provide (1) a regional interpretive framework for evaluating earthquake (faultrupture and ground shaking) and landslide hazards, (2) detailed mapping that can support local and regional hazard assessments. Both contributions are particularly relevant in densely populated regions of hazard-prone California.

- Energy and mineral resources programs.-NCGMP framework studies have contributed to assessment of resources as well as impacts of extraction of those resources.
- National Geospatial Program.-Lidar acquisition will aid in detailed mapping of faults and geomorphic features that tie to earthquake, volcano, landslide, and flood hazards.

\section{Other Federal Agencies}

NCGMP field investigations provide a regional framework and detailed mapping for land-use and natural-resources management for multiple agencies, including the following.

- National Park Service

- Bureau of Land Management

- U.S. Forest Service

- Bureau of Reclamation

- Department of Defense facilities (for example, Vandenberg Air Force Base)

\section{State and Local Agencies}

- California Geological Survey.-NCGMP field investigations contribute to State 1:100,000-scale mapping efforts and provide input to California Geological Survey in its Alquist-Priolo (re)evaluation of fault zones and evaluation of alluvial-fan flood hazards.

- California Department of Water Resources. - This agency has cooperated with ongoing efforts in characterizing the geohydrologic framework by providing water well lithologic data. Closer collaboration and cooperation should be pursued for planning our 2D and 3D mapping efforts.

- County and local governments.-NCGMP investigations have been funded and utilized by county and local governments to provide scientific expertise to groundwater investigations and seismic hazard assessments.

\section{Private Industry}

Private industry, particularly the Pacific Gas and Electric Company, represents a substantial user base, and at times a funding source, for 2D and 3D mapping science in support of hazard assessment of its infrastructure.

\section{Academic Entities}

- Southern California Earthquake Center

- Various university geoscience departments in support of FEDMAP proposals 


\section{Anticipated Outcomes}

1. Improved earthquake hazard modeling through improved $3 D$ seismic velocity models and improved parameterization of earthquake sources.-Through development of new 3D geologic maps and improvements in methods used to assign seismic velocities to them, along with work to better integrate geology-based models with tomographic models, we will improve a basic dataset needed for calculation of transmission of earthquake energy through the upper crust and resultant ground shaking. Through analysis of surface and subsurface fault geometry and connectivity we will improve understanding of potential earthquake size and type, as well as better define ground rupture hazards related to complex fault zones and systems.

2. Improved geohydrologic frameworks for groundwater modeling.-Through 3D geologic and physical property modeling of basin aquifers, we will improve geohydrologic frameworks for the northern Sacramento Valley, Salinas valley, Russian River watershed, and San Antonio Basin.

3. Improved understanding and interpretation of geologic resources of Pinnacles National Park.-New geologic mapping and paleontology will better define the geology and geologic history of the eastern half of the park.

4. Updated and consolidated geologic map of the Sierra Nevada.-The combination of geologic, geophysical, radiometric age, and paleontological datasets will provide the foundation for improved land-management decisions in a rapidly developing region and new general-audience outreach products for a popular tourist area.

\section{References Cited}

Brock, J., Berry, K., Faulds, J., Berg, R., House, K., Marketti, M., McPhee, D., Schmidt, K., Schmitt, J., Soller, D., Spears, D., Thompson, R., Thorleifson, H., and Walsh, G., in press, Renewing the National Cooperative Geologic Mapping Program as the Nation's Authoritative Source for Modern Geologic Knowledge: U.S. Geological Survey Open-File Report 2021-1013, https://doi.org/10.3133/ ofr20211013.

Drenth, B.J., and Grauch, V.J.S., 2019, Finding the gaps in America's magnetic maps: Eos, v. 100, accessed January 24, 2020, at https://doi.org/10.1029/2019EO120449.

Fenneman, N.M., 1917, Physiographic subdivisions of the United States: Proceedings of the National Academy of Sciences, v. 3, p. 17-22.

Fenneman, N.M., 1928, Physiographic divisions of the United States (3rd revision with map): Annals of the Association of American Geographers, v. 18, no. 4. p. 261-353.

Fenneman, N.M., 1946, Physical divisions of the United States: U.S. Geological Survey Report, scale 1:7,000,000.

Johnson, M.R., Anderson, E.D., Ball, L.B., Drenth, B.J., Grauch, V.J.S., McCafferty, A.E., Scheirer, D.S., Schweitzer, P.N., Shah, A.K., and Smith, B.D., 2019, Airborne geophysical survey inventory of the conterminous United States, Alaska, Hawaii, and Puerto Rico: U.S. Geological Survey data release, accessed January 25, 2020, at https://doi.org/10.5066/P9K8YTW1.
Moffett Field Publishing Service Center, California

Manuscript approved February 12, 2021

Edited by Aditya Navale

Layout by Cory Hurd 


\section{$\frac{2}{2}$}

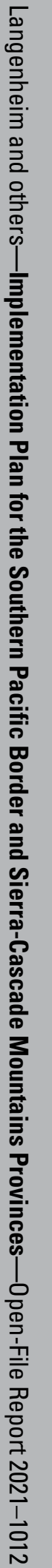

